\title{
Helicobacter Pylori Infection Associated Diseases - A Systematic Review
}

\author{
Shunan $\mathrm{Li}^{1}$, Ming Liu ${ }^{1}$, Esterlina Garcia ${ }^{2^{*}}$, Wenxing $\mathrm{Hu}^{3^{*}}$ \\ ${ }^{1}$ Department of Electrical, Computer, and Biomedical Engineering, the \\ University of Rhode Island, Kingston, RI 02881, USA; \\ ${ }^{2}$ Howard-Tilton Library, Tulane University, 7001 Freret St, New Orleans, LA \\ 70118, USA; \\ ${ }^{3}$ Department of Biomedical Engineering, Tulane University. 1440 Canal St, \\ New Orleans, LA 70112, USA.
}

Corresponding to: Esterlina Garcia, Department of Biomedical Engineering, Tulane University. 1440 Canal St, New Orleans, LA 70112. Email: egarcia7@tulane.edu; or Wenxing Hu, Department of Biomedical Engineering, Tulane University. 1440 Canal St, New Orleans, LA 70112, USA. Email: whu@tulane.edu.

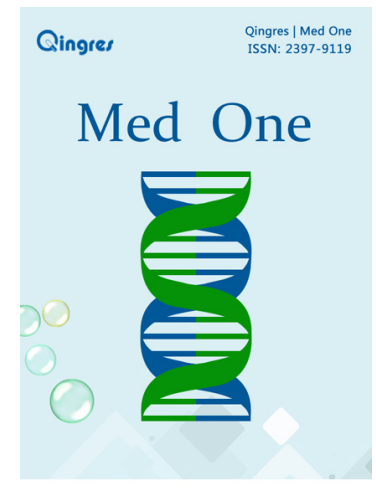

http://mo.qingres.com

\section{GOPEN ACCESS}

DOI: $10.20900 / \mathrm{mo} .20170007$

Received: January 18, 2017

Accepted: March 15, 2017

Published: April 25, 2017

Copyright: ๑2017 Cain et al. This is an open access article distributed under the terms of the Creative Commons Attribution License, which permits unrestricted use, distribution, and reproduction in any medium, provided the original author and source are credited.

\section{ABSTRACT}

Helicobacter pylori (H. pylori) infection (HPI) is one of the most widespread diseases. More than half of world population is affected by HPI, especially children in developing countries. The associations between many gastrointestinal diseases and HPI have been found in clinical. Also, there are some diseases whose HPI associations are controversial and unclear. Due to its unclear disease association, $H$. pylori test is not included in the clinical screening. However, some pre-clinical studies showed possible associations between HPI and these diseases, involving pathological changes of different functional systems of the human body (e.g., Immune system, cerebrovascular system). Therefore, for HPI patients, more attention should be paid to the possible risks of these diseases. In this study, a systematic literature review was conducted to identify and classify $H$. pylori related diseases. This review identified $175 \mathrm{HPI}$ related diseases belonging to 9 categories, and summarized the corresponding supporting literature reports. In addition, the functional mechanisms underlying the linkages between $\mathrm{HPI}$ and 28 well studied diseases were discussed, revealing possible pathogenesis for these diseases. We conclude that $\mathrm{HPI}$ is related to many serious diseases affecting multiple important human systems, and clinical HPI treatment and HPI test might help the detection and treatment of these diseases. Our results guarantee further study using more data to testify the possible relations between $\mathrm{HPI}$ and these diseases.

Key words: H. pylori infection; classifications; diseases 


\section{INTRODUCTION}

$H$. pylori is a gram-negative and microaerophilic b acterium, usually found in the stomach. Although up to $85 \%$ of people infected with $H$. pylori never express any symptoms or complications, more than half of world population are infected by $H$. Pylori ${ }^{[1]}$. In 1982, H. Pylori was first discovered by two Australian scientists, Barry Marshall and Robin Warren ${ }^{[2]}$. (reference fontsize) Before that, human gastric ulcers were believed to be caused by stress, spicy foods, smoking, and other malignant habits. Nevertheless, recent epidemiologic and clinical studies have proved that HPI is the main cause for gastric and duodenal diseases. Additionally, HPI has been linked to the pathogenic development of gastric adenocarcinoma ${ }^{[3]}$, the second leading cause of cancer-related death ${ }^{[4]}$.

AcuteHPI may appear as an acute gastritis or nausea ${ }^{[5]}$. Individuals infected with $H$. pylori have $10 \%$ to $20 \%$ lifetime risk of developing peptic ulcers, and $1 \%$ to $2 \%$ increased risk of developing stomach cancer ${ }^{[6,7]}$. The pyloric antrum inflammation leads to duodenal ulcers, while inflammation of the corpus leads to gastric ulcers and gastric carcinoma ${ }^{[8]}$. A study showed that HPI was related to gastric cancer and the risk of developing gastric cancer was reduced from $1.7 \%$ to $1.1 \%$ with HPI treatment ${ }^{[9]}$.

In addition, $H$. pylori is also reported to be associated with non-gastrointestinal related disease, including hematological diseases, cardiovascular diseases, and neurological disorders. However, the clinical checks of most of these non-stomachic diseases do not include HPI screening check due to the controversial and unclear HPI association. This review summarizes some previous studies conducted before 2016 exploring possible associations between HIP and other diseases, to identify diseases that could use HPI as their clinical indicators.

Table 1. $H$. pylori infection related diseases

\section{METHODS AND MATERIALS}

We performed a literature search through PubMed, ScienceDirect and Elsevier journal papers. In total, 2,070 articles published from January 1990 to December 2016 were covered, which report potential relations between $\mathrm{HPI}$ and some diseases. There were 175 different diseases or symptoms extracted from the literatures, and their detailed information is listed in the Supplementary Data, including the disease name, category, status of association with $\mathrm{HPI}$ and the number of supporting references. In this work, we focused our discussion on diseases meeting the following criterions: 1) with no less than 5 papers supporting positive HPI associations; or 2) with at least one paper reporting negative/ controversial/no association. Also, these diseases were classified based on the human body system they were related to.

\section{RESULTS}

There were 28 different diseases of 9 categories that satisfied the disease selection criteria, which were summarized in Table 1. In total, 1,539 articles (74.3\% of 2070 ) reported positive associations between digestive-system-related diseases and $\mathrm{HPI}$. Positive HPI affections were also found in atherosclerosis and myocardial ischemia, Alzheimer disease, Parkinson disease, chronic urticarial, and diabetes mellitus. Negative affections were observed in immune response, including asthma, allegic rhinitis, and digestive diseases that are related to peptic acid secretion (e.g., esophagitis, esophageal adenocarcinoma, hyperchlorhydria and inflammatory bowel diseases). Liver cirrhosis, anemia, idiopathic thrombocytopenic purpura, cerebral infarction, hyperemesis gravidarum, and obesity were reported to have controversial HPI associations.

\begin{tabular}{|c|c|c|c|}
\hline Category & Disease & Association & numbers of literatures \\
\hline \multirow[t]{5}{*}{ Digestive } & Gastric Carcinoma & + & 602 \\
\hline & Gastritis & + & 396 \\
\hline & Peptic Ulcer & + & 259 \\
\hline & Gastric Lymphoma & + & 87 \\
\hline & Gastric Ulcer & + & 78 \\
\hline
\end{tabular}




\begin{tabular}{|c|c|c|c|}
\hline & Duodenal Ulcer & + & 76 \\
\hline & Intestinal Metaplasia & + & 23 \\
\hline & Esophagitis & + & 9 \\
\hline & Hypochlorhydria & + & 9 \\
\hline & Esophagitis & - & 9 \\
\hline & Liver Cirrhosis & $+/-$ & $\begin{array}{c}6 \\
\text { (positive 4; no association 2) }\end{array}$ \\
\hline & Inflammatory Bowel Diseases & - & 4 \\
\hline & Cardia Carcinoma & - & 1 \\
\hline & Esophageal Adenocarcinoma & - & 1 \\
\hline & Hyperchlorhydria & - & 1 \\
\hline \multirow[t]{3}{*}{ Immune } & Asthma & - & 4 \\
\hline & Allergic Rhinitis & - & 2 \\
\hline & Chronic Urticaria & + & 8 \\
\hline \multirow[t]{2}{*}{ Hematological } & Iron Deficiency Anemia & $+/-$ & $\begin{array}{c}42 \\
\text { (positive 27; no association } \\
18 \text { ) }\end{array}$ \\
\hline & Idiopathic Thrombocytopenic Purpura & $+/-$ & $\begin{array}{c}24 \\
\text { (positive 19; no association 5) }\end{array}$ \\
\hline Endocrine & Diabetes Mellitus & + & 18 \\
\hline \multirow[t]{2}{*}{ Cardiovascular } & Ischemic Heart Disease & + & 32 \\
\hline & Atherosclerosis & + & 17 \\
\hline Cerebrovascular & Cerebral Infarction & $+/-$ & $\begin{array}{c}13 \\
\text { (positive 8; no association 5) }\end{array}$ \\
\hline \multirow[t]{2}{*}{ Neurological } & Alzheimer Disease & + & 6 \\
\hline & Parkinson Disease & + & 5 \\
\hline Reproductive & Hyperemesis Gravidarum & $+/-$ & $\begin{array}{c}6 \\
\text { (positive 4; no association 2) }\end{array}$ \\
\hline Growth \& & & & 7 \\
\hline Development & Obesity & $+/-$ & $\begin{array}{l}\text { (positive 2; negative3; no } \\
\text { association 2) }\end{array}$ \\
\hline
\end{tabular}

Note: +: positive; -: negative; +/-: controversial 


\subsection{Digestive diseases}

HPI plays an important role in severe digestive diseases including chronic gastritis, peptic ulcer disease, gastric MALT Iymphoma and gastric cancer ${ }^{[10]}$. HPI was found in $89.8 \%$ of chronic gastritis patients ${ }^{[11]}$. Fig. 1 shows the gastrointestinal disease progression induced by HPI.

$\mathrm{HPI}$ is recognized as a clinical marker for the risk of gastric cancer. It has been shown that HPI could induce gastric cancer through multiple pathogenic steps ${ }^{[12-14]}$. Chronic gastritis have been demonstrated to be the main cause of gastric MALT lymphoma in HPI patients, and MALT Iymphoma induced tumor regression in $70 \%$ to $80 \%$ of patients ${ }^{[15-17]}$.
Recently, it was found that patients with chronic gastritis caused by HPI have a three times greater risk of developing gastric cancer compared with control groups without $\mathrm{HPI}{ }^{[18]}$.

HPI causes chronic gastritis with a mucosal infiltration caused by inflammatory cells ${ }^{[19]}$. In most cases HPI patients remain asymptomatic for a long time ${ }^{[20]}$. Due to the fact that $H$. pylori is covered by the mucous layer, it is hard for the immune systems to eliminate the bacterium colonized at the epithelial cells of the stomach ${ }^{[21]}$. Chronic HPI could lead to gastric damage associated with digestive problems, and it is dependent on both host and bacterial factors, which is different from many other infections [22-23]

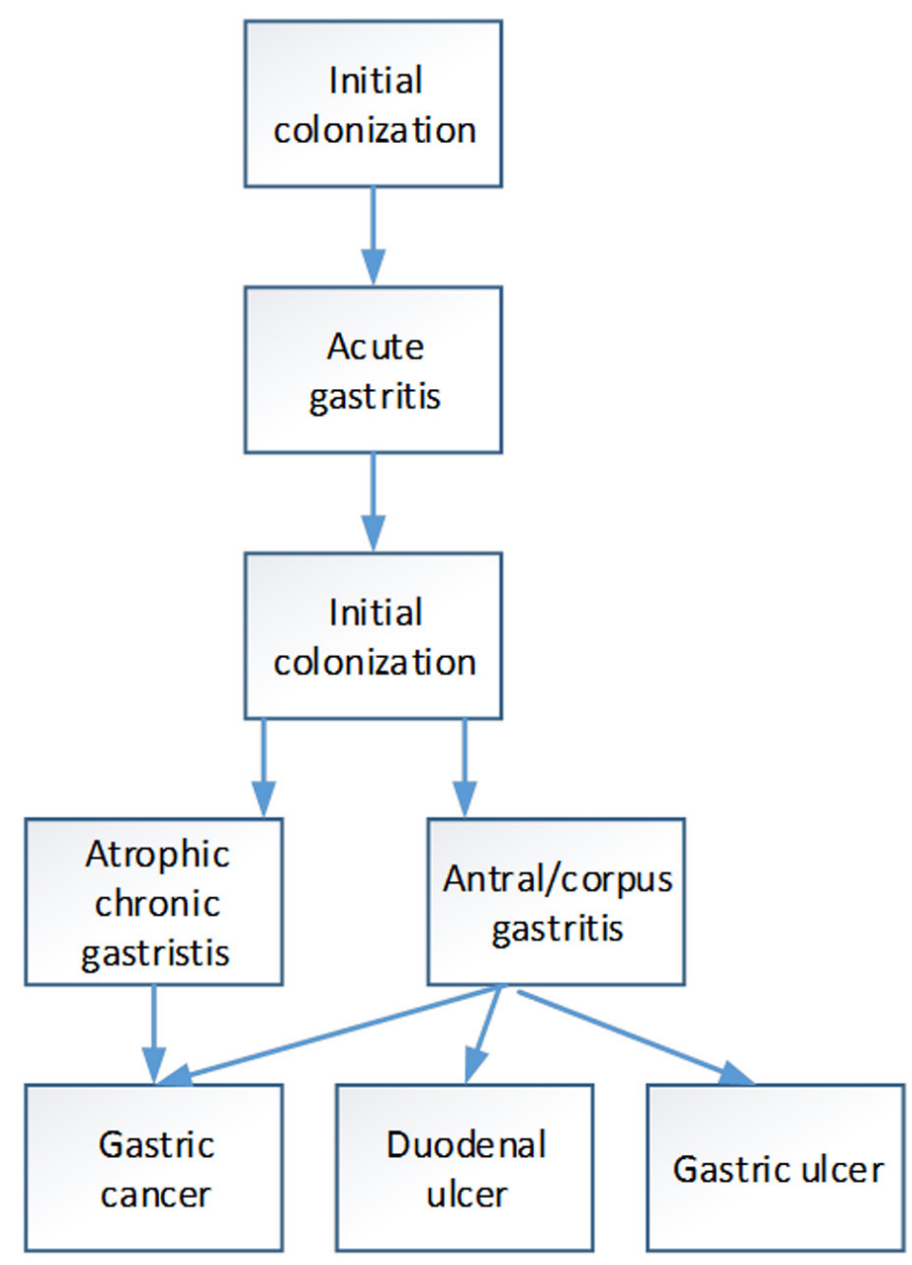

Fig. 1 The $H$. pylori induced gastrointestinal diseases. 
HPI has been reported to have a negative association with hyperchlorhydria ${ }^{[24]}$, eosinophilic oesophagitis ${ }^{[25]}$ and reflux esophagitis after esophagectomy ${ }^{[26,27]}$. In most cases, acute HPI reduces stomach acid secretion at the beginning. The reduced stomach acid secretion usually returns to the normal level after a few months. HPI induces atrophic in the mucosa, leading to persistent hypochlorhydria caused by secretory tissue atrophic. In the early period of esophagogastrostomy, bile reflux could cause reflux esophagitis that is related to $\mathrm{HPI}{ }^{[26,27]}$. The results from Arnim et al.'s study showed that the control group presented significantly higher seroprevalence of $H$. pylori compared to that of patients with esophagitis ${ }^{[25]}$. Nishimura et al. reported that the level of gastric acidity in patients with $\mathrm{HPI}$, were significantly lower than that in patients without $\mathrm{HPI}^{[26]}$.

Some studies suggested that Cirrhosis was positively associated with HPI. However, other studies did not observe significant relations between $\mathrm{HPI}$ and Cirrhosis. A recent meta-analysis ${ }^{[27]}$ showed a significant difference of cirrhosis rates between HPI patients and healthy controls [odd ratio (OR) $=2.05,95 \%$ confidence interval $(\mathrm{Cl}): 1.3-3.18, p$ $<0.0001]$. However, no significant difference were found in the studies using Asian subjects (OR = $0.90,95 \% \mathrm{Cl}: 0.48-1.66, p<0.0001)^{[28]}$. These conflicting results may be caused by the geographic and race difference of the participants.

\subsection{Hematological diseases}

Iron deficiency anemia (IDA) has controversial HPI association reports. IDA may be induced by $\mathrm{HPI}$ ${ }^{[29-32]}$. Gastrointestinal diseases linked to HPI may cause the inadequate iron intake or chronic blood loss. Dufour et al. were the first to indicate the relation between IDA and $H$. pylori ${ }^{[29]}$ which was supported by a lower ferritin level in HPI patients ${ }^{[30-}$ ${ }^{32]}$. Chronic blood loss may be caused by ulcer. The other possible IDA pathogenesis may include the impaired iron absorption caused by atrophic gastritis

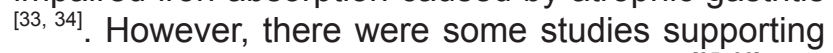
negative associations between $\mathrm{HPI}$ and IDA ${ }^{[35,36]}$.

The results on the association between $\mathrm{HPI}$ and idiopathic thrombocytopenic purpura (ITP) were also controversial. Some studies showed a prevalence of HPI patients with ITP ${ }^{[37-39]}$. However, these studies have no control groups. Campuzano-Maya presented a higher prevalence of ITP in patients with HPI than the control group ${ }^{[40]}$. On the contrary, Michel et al. did not find any significant difference in ITP prevalence between the HPI group and the control group ${ }^{[41]}$.

\subsection{Cardiovascular diseases}

It has been suggested that $H$. pylori plays an important role in ischemic heart disease (IHD). HPI may induce deficiency of folate and vitamins. Thereby, HPI might be involved in coronary heart disease pathogenesis ${ }^{[42]}$. However, some studies have reported conflicting results ${ }^{[43-46]}$. There may be false positives in IHD patients, which is more related to age and social status ${ }^{[46]}$. Danesh et al. conducted a meta-analysis and observed no significant positive association between $H$. pylori and $\mathrm{CHD}^{[47]}$. Some studies reported that more serious coronary atherosclerosis was observed in patients with $H$. pylori CagA+ strains infection ${ }^{[48-50]}$.

\subsection{Cerebrovascular disorders}

The potential HPI associations of ischemic atherosclerotic stroke and vascular dementia have also been proposed. Sawayama et al. suggested that chronic HPI may increase the risk of acute ischemic stroke. Their study results showed that chronic $H$. pylori infection was related to a higher risk of stroke caused by small artery occlusion (odds ratio: 9.68; $95 \%$ Cl: 3.56-33.08, $p<0.001$ ), but a lower risk of cardioembolic stroke (odds ratio: 0.27 ; $95 \% \mathrm{Cl}$ : 0.03-1.53), and an overall association with ischemic stroke (odds ratio for all subtypes combined: 2.57; $95 \%$ Cl: 1.09-6.08) after adjusting major cardiovascular risk factors ${ }^{[51]}$. However, there were conflicting results on the relevance of chronic infection by $\mathrm{H}$. pylori as a risk factor for ischemic stroke. For instance, a case-control study by Yang et al. failed to identify any strong association between chronic HPI and ischemic stroke ${ }^{[52]}$. Additionally, the meta-analysis by $\mathrm{Yu}$ et al. indicated no significant association between $\mathrm{HPI}$ and ischemic stroke ${ }^{[53]}$.

The proposed mechanism linking $H$. pylori to ischemic stroke is similar to that of IHD. CagA+ strains had been shown to increase the risk of ischemic stroke by affecting the instability of carotid plaque ${ }^{[54-59]}$. Cross-reacting antibody is a risk factor for carotid atherosclerosis ${ }^{[60]}$. An alternative explanation for the relationship between cerebrovascular disease and HPI was the hyperhomocysteinemia ${ }^{[61]}$, although it was not confirmed by Markus and Mendall ${ }^{[62]}$.

\subsection{Neurological disorders}


$\mathrm{HPI}$ is one of the infections which have been implicated as risk factors for cognitive impairment, dementia and Alzheimer's disease (AD) ${ }^{[63-64]}$. Kountouras et al. demonstrated a significantly higher prevalence of $\mathrm{HPI}^{[65]}$ and anti-H. pylori specific IgG in the cerebrospinal fluid of patients with $A D^{[66]}$.

$H$. pylori may also trigger Pakinson disease. The eradication of $H$. pylori could change the course of idiopathic parkinsonism ${ }^{[67]}$ and improve the pharmacokinetic and clinical response to L-dopa in patients with idiopathic parkinsonism by increasing the L-dopa absorption ${ }^{[68]}$. Schulz et al. supported this theory and stated that cholesterol glucosides may be raised by $\mathrm{HPI}^{[69]}$.

\subsection{Immune response}

Negative HPI associations have been reported with several allergic diseases including atopy, asthma and allergic rhinitis ${ }^{[70-72]}$. Evidence from epidemiological studies suggested HPI accounted for an estimated $18 \%$ reduction in odds of atopy ${ }^{[70]}$. Sheptulin et al. suggested a negative HPI association in bronchial asthma and chronic inflammatory intestinal diseases [71]. Reibman also proposed a hypothesis that colonization with $\mathrm{CagA}+\mathrm{H}$. pylori strains had a negative association with asthma ${ }^{[72]}$. Experimental by Arnold et al. suggested that HPI could exerted a beneficial effect in mouse with asthma ${ }^{[73]}$.

\subsection{Diabetes mellitus}

$H$. pylori infection is reported to be associated with insulin resistance, diabetes mellitus and metabolic syndrome ${ }^{[74-76]}$. Compared to non-diabetics with $\mathrm{HPI}$, the levels of oxidative DNA damage (8-OHdG) in type 2 diabetes mellitus could be much higher $(p=0.001)$. In addition, 8-OHdG levels of these HPI non-diabetics were also higher than that of type 2 diabetes mellitus with negative $H$. pylori. These results showed a pathogenic linkage between HPI and diabetes ${ }^{[74]}$. There were significant differences of fasting blood glucose, high-density lipoprotein cholesterol between HPI patients and healthy controls ${ }^{[75]}$. Hsieh et al. reported that long-term HPI was significantly associated with increased levels of $\mathrm{HbA} 1 \mathrm{c}$ and decreased insulin secretion in Chinese population ${ }^{[76]}$.

\subsection{Hyperemesis gravidarum}

H. pylori infection may cause hyperemesis gravidarum (HG). Serologically positive HPI was detected in 44 out of 54 patients with hyperemesis gravidarum $(81.5 \%)$ whereas 29 out of 53 asymptomatic gravidas $(54.7 \%$ ) had positive antibody titers for Helicobacter pylori, and the ratio of Helicobacter pylori seropositivity in pregnant women with hyperemesis gravidarum was significantly higher than that of asymptomatic pregnant women $(p<0.01)^{[77]}$. This positive association was also confirmed in several other studies ${ }^{[78,79]}$. However, some conflicting results were also identified in some other studies ${ }^{[80-81]}$, making the HPI-HG relation more complicated.

\subsection{Obesity}

It was reported that the association between HPI and obesity could be both positive ${ }^{[82-83]}$ and negative [84-85]. For example, leptin and ghrelin are important appetite hormones secreted from the stomach. They play important roles in the coordination of eating behavior and weight regulation. It was found that the eradication of $H$. pylori was associated with a significant increase in leptin levels and body mass index (BMI) in pre-pubertal children with $\mathrm{H}$. pyloriassociated gastritis ${ }^{[86]}$. Azuma et al. demonstrated that $H$. pylori eradication could increase $\mathrm{BMI}^{[87]}$. Nweneka and Prentice presented a systematic review and found that 17 studies showed lower circulating ghrelin levels in $H$. pylori-positive patients while 10 studies reported no difference, and the meta-analysis of 19 studies involving 1,801 patients showed a significantly higher circulating ghrelin concentration in $H$. pylori -negative individuals, but $H$. pylori eradication did not alter the ghrelin levels ${ }^{[88]}$.

\section{CONCLUSION}

HPI is one of the most widespread diseases worldwide, and has been reported to be associated with many diseases affecting multiple functional systems of human body. In this paper, we conducted a systematical literature review in order to detect diseases that have clear and confirmed HPI associations. Clinical and epidemiological cases in some studies showed strong evidences of positive $H$. pylori associations in some diseases, especially some gastrointestinal diseases, e.g. gastritis and gastric carcinoma, gastric lymphoma. In contrast, H. pylori association patterns in several diseases from some other human systems remains unclear with controversial conclusions. One possible reason is that $H$. pylori test is not a routine test for non-gastrointestinal diseases. More data are 
needed in order to test the role that HPI plays in the pathogenesis of these non-gastrointestinal diseases.

\section{CONFLICT OF INTERESTS}

Authors claim no conflict of interests.

\section{REFERENCES}

1. Jayakar AV, Vanitha A. Helicobacter Pylori Infection. RAP Gastroenterol Hepatol Nutri. 1983; 6: 23.

2. Bytzer P, Teglbjaerg PS; Danish Ulcer Study Group. Diagnosis and treatment of Helicobacter pylori infection. Dan Med Bull. 2011; 58(4): C4271.

3. Graham DY. Helicobacter pylori infection is the primary cause of gastric cancer. J Gastroenterol. 2000; 35: 90-97.

4. Ebert MP, Yu J, Sung JJ, Malfertheiner P. Molecular alterations in gastric cancer: the role of Helicobacter pylori. Eur J Gastroenterol Hepatol. 2000; 12(7): 795-798.

5. Greco S. Self-Assessment Colour Review of Gastroenterology. Forbes A, Gilinsky NH, editors. London: Manson Publishing Ltd.; 2003.

6. Chang $\mathrm{AH}$, Parsonnet $\mathrm{J}$. Role of bacteria in oncogenesis. Clin Microbiol Rev. 2010; 23(4): 837-857.

7. Kusters JG, Van AH, Kuipers EJ. Pathogenesis of Helicobacter pylori infection. Clin Microbiol Rev. 2006; 19(3): 449-490.

8. Suerbaum S, Michetti P. Helicobacter pylori infection. New Engl J Med. 2002; 347(15): 11751186.

9. Fuccio L, Zagari RM, Eusebi LH, Laterza L, Cennamo V, Ceroni L, Grilli D, Bazzoli F. Metaanalysis: can Helicobacter pylori eradication treatment reduce the risk for gastric cancer? Ann Intern Med. 2009; 151(2): 121-128.

10. Abadi AT, Kusters JG. Management of Helicobacter pylori infections. BMC Gastroenterol. 2016; 16(1): 94.

11. Alcalde $M$, Sánchez $P$, Lancho $A$, Rodríguez $S$, Carpintero P, Pajares JM. [Chronic gastritis and Helicobacter pylori in patients with non-ulcerous dyspepsia. Role and significance of age]. An Med Interna. 1995; 12(7): 317-320.
12. Zak M, Pasiyeshvili L. Chronic Gastritis Clinical features and Stomach Functional State during Nonsteroidal Anti-Inflammatory Drugs Administration in Patients with Osteoarthritis. Eureka: Health Sciences. 2016; 5: 17-22.

13. Kuligowski J, Sanjuanherráez D, Vázquezsánchez MA, Brunetvega A, Pericay C. Metabolomic Analysis of Gastric Cancer Progression within the Correa's Cascade Using Ultraperformance Liquid Chromatography-Mass Spectrometry. J Proteome Res. 2016; 15(8): 2729-2738.

14. Arismendi-Morillo G, Hernández I, Mengual E, Abreu N, Molero N, Fuenmayor A, Romero G, Lizarzábal M. Estimación de riesgo de cáncer gástrico en pacientes con gastritis crónica asociada a la infección por Helicobacter pylori en un escenario clínico. Rev Gastroenterol Mex. 2013; 78(3): 135-143.

15. Raef T. Criteria for extra-label drug use debated at FDA Advisory Committee meeting. J Amer Vet Med Assn. 1995; 207(1): 10-11.

16. Dada SA, Fuhrman GM. Miscellaneous disorders and their management in gastric surgery: volvulus, carcinoid, lymphoma, gastric varices, and gastric outlet obstruction. Surg Clin North Am. 2011; 91(5): 1123-1130.

17. Ho S. Premalignant lesions of the stomach. Semin Gastrointest Dis. 1996; 7(2): 61-73

18. Uemura N, Okamoto $S$, Yamamoto $S$, Matsumura $\mathrm{N}$, Yamaguchi S, Yamakido M, Taniyama K, Sasaki N, Schlemper RJ. Helicobacter pylori infection and the development of gastric cancer. N Engl J Med. 2001; 345(11): 784-789.

19. Betten A, Bylund J, Christophe T, Boulay F, Romero A, Hellstrand K, Dahlgren C. A proinflammatory peptide from Helicobacter pylori activates monocytes to induce lymphocyte dysfunction and apoptosis. J Clin Invest. 2001; 108(8): 1221-1228.

20. Nicolson GL, Haier J. Role of Chronic Bacterial a Role of Chronic Bacterial and Viral Infections in Neurodegenerative, nd Viral Infections in Neurodegenerative, Neurobehavioral, Psychiatric, Autoimmune and Fatiguing Illnesses: Part 1. Brit J Med Pract. 2009; 2(4): 20-28.

21. Abadi AT. Therapy of Helicobacter pylori: present medley and future prospective. Biomed Res Int. 2014; 2014: 124607.

22. Abadi AT, lerardi E, Lee YY. Why do we still have Helicobacter Pylori in our Stomachs? Malays J 
Med Sci. 2015; 22(5): 70-75.

23. Mazzucchelli L, Blaser $A$, Kappeler A, Schärli $P$, Laissue JA, Baggiolini M, Uguccioni M. BCA1 is highly expressed in Helicobacter pyloriinduced mucosa-associated lymphoid tissue and gastric lymphoma. J Clin Invest. 1999; 104(10): R49-R54.

24. Cater R. Helicobacter (aka Campylobacter) pylori as the major causal factor in chronic hypochlorhydria. Med hypotheses. 1992; 39(4): 367-374.

25. Von Arnim U, Wex T, Link A, Messerschmidt M, Venerito M, Miehlke S, Malfertheiner P. Helicobacter pylori infection is associated with a reduced risk of developing eosinophilic oesophagitis. Aliment Pharmacol Ther. 2016; 43(7): 825-830.

26. Mori N, Fujita H, Sueyoshi S, Aoyama Y, Yanagawa T, Shirouzu K, Helicobacter pylori infection influences the acidity in the gastric tube as an esophageal substitute after esophagectomy. Dis Esophagus. 2007; 20(4): 333-340.

27. Nishimura K, Tanaka T, Tsubuku T, Matono S, Nagano T, Murata K, Aoyama Y, Yanagawa T, Shirouzu K, Fujita H. Reflux esophagitis after esophagectomy: impact of duodenogastroesophageal reflux. Dis Esophagus. 2012; 25(5): 381-385.

28. Feng $\mathrm{H}$, Zhou X, Zhang G. Association between cirrhosis and Helicobacter pylori infection: a meta-analysis. Eur J Gastroenterol Hepatol. 2014; 26(12): 1309-1319.

29. Dufour C, Brisigotti M, Fabretti G, Luxardo P, Mori PG, Barabino A. Helicobacter pylori gastric infection and sideropenic refractory anemia. J Pediat Gastroenterol Nutr. 1993; 17(2): 225-227.

30. Cardenas VM, Mulla ZD, Ortiz M, Graham DY. Iron deficiency and Helicobacter pylori infection in the United States. Amer J Epdemiol. 2006; 163(2): 127-134.

31. Milman N, Rosenstock S, Andersen L, Jorgensen T, Bonnevie O. Serum ferritin, hemoglobin, and Helicobacter pylori infection: a seroepidemiologic survey comprising 2794 Danish adults. Gastroenterology. 1998; 115(2): 268-274.

32. Muhsen K, Cohen D. Helicobacter pylori Infection and Iron Stores: A Systematic Review and Meta-analysis. Helicobacter. 2008; 13(5): 323-340.

33. Ciacci C, Sabbatini F, Cavallaro R, Castiglione
F, Di Bella S, lovino P, Palumbo A, Tortora R, Amoruso D, Mazzacca G. Helicobacter pylori impairs iron absorption in infected individuals. Dig Liver Dis. 2004; 36(7): 455-460.

34. Lombard M, Chua E, O'toole P. Regulation of intestinal non-haem iron absorption. Gut. 1997; 40(4): 435.

35. Choi J, Does H. Helicobacter pylori infection relate to iron deficiency anaemia in prepubescent children under 12 years of age? Acta Paediat. 2003; 92(8): 970-972.

36. Collett JA, Burt MJ, Frampton CM, Yeo KH, Chapman TM, Buttimore RC, Cook HB, Chapman BA. Seroprevalence of Helicobacter pylori in the adult population of Christchurch: risk factors and relationship to dyspeptic symptoms and iron studies. N Z Med J. 1999; 112(1093): 292-295.

37. Gasbarrini A, Franceschi F, Tartaglione R, Landolfi R, Pola P, Gasbarrini G. Regression of autoimmune thrombocytopenia after eradication of Helicobacter pylori. Lancet. 1998; 352(9131): 878.

38. Kohda K, Kuga T, Kogawa K, Kanisawa Y, Koike K, Kuroiwa G, Hirayama Y, Sato Y, Niitsu Y. Effect of Helicobacter pylori eradication on platelet recovery in Japanese patients with chronic idiopathic thrombocytopenic purpura and secondary autoimmune thrombocytopenic purpura. Brit J Haematol. 2002; 118(2): 584-588.

39. Sivapathasingam V, Harvey MP, Wilson RB. Helicobacter pylori eradication: a novel therapeutic option in chronic immune thrombocytopenic purpura. Med J Australia. 2008; 189(7): 367.

40. Campuzano-Maya G. Proof of an association between Helicobacter pylori and idiopathic thrombocytopenic purpura in Latin America. Helicobacter. 2007; 12(3): 265-273.

41. Michel M, Khellaf M, Desforges L, Lee K, Schaeffer A, Godeau B, Bierling P. Autoimmune thrombocytopenic purpura and Helicobacter pylori infection. Arch Intern Med. 2002; 162(9): 1033-1036.

42. Rothenbacher D, Fischer HG, Hoffmeister A, Hoffmann MM, März W, Bode G, Rosenthal $\mathrm{J}$, Koenig W, Brenner $\mathrm{H}$. Homocysteine and methylenetetrahydrofolate reductase genotype: association with risk of coronary heart disease and relation to inflammatory, hemostatic, and lipid parameters. Atherosclerosis. 2002; 162(1): 193-200. 
43. Patel $P$, Mendall MA, Carrington $D$, Strachan DP, Leatham E, Molineaux N, Levy J, Blakeston C, Seymour CA, Camm AJ, Association of Helicobacter pylori and Chlamydia pneumoniae infections with coronary heart disease and cardiovascular risk factors. BMJ. 1995; 311(7007): 711-714.

44. Kinjo K, Sato $H$, Sato $H$, Shiotani I, Kurotobi $T$, Ohnishi Y, Hishida E, Nakatani D, Mizuno H, Sasaki T, Kohama A, Abe Y, Morita H, Kubo M, Takeda H, Hori M. Prevalence of Helicobacter pylori infection and its link to coronary risk factors in Japanese patients with acute myocardial infarction. Circ J. 2002; 66(9): 805810.

45. Folsom AR, Nieto FJ, Sorlie P, Chambless LE, Graham DY. Helicobacter pylori seropositivity and coronary heart disease incidence. Circulation. 1998; 98(9): 845-850.

46. McDonagh TA, Woodward M, Morrison CE, McMurray JJ, Tunstall-Pedoe H, Lowe GD, McColl KE, Dargie HJ. Helicobacter pylori infection and coronary heart disease in the North Glasgow MONICA population. Eur Heart J. 1997; 18(8): 1257-1260.

47. Danesh J, Peto R. Risk factors for coronary heart disease and infection with Helicobacter pylori: meta-analysis of 18 studies. BMJ. 1998; 316(7138): 1130-1132.

48. Huang B, Chen Y, Xie Q, Lin G, Wu Y, Feng Y, Li J, Zhuo Y, Zhang P. CagA-positive Helicobacter pylori strains enhanced coronary atherosclerosis by increasing serum OxLDL and HsCRP in patients with coronary heart disease. Digest Dis Sci. 2011; 56(1): 109-114.

49. Singh RK, McMahon AD, Patel H, Packard CJ, Rathbone BJ, Samani NJ. Prospective analysis of the association of infection with CagA bearing strains of Helicobacter pylori and coronary heart disease. Heart. 2002; 88(1): 43-46.

50. Khodaii Z, Vakili H, Ghaderian SM, Najar RA, Panah AS. Association of Helicobacter pylori infection with acute myocardial infarction. Coronary Artery Dis. 2011; 22(1): 6-11.

51. Sawayama Y, Ariyama I, Hamada M, Otaguro S, Machi T, Taira Y, Hayashi J. Association between chronic Helicobacter pylori infection and acute ischemic stroke: Fukuoka Harasanshin Atherosclerosis Trial (FHAT). Atherosclerosis.2005; 178(2): 303-309.

52. Yang X, Gao Y, Zhao X, Tang Y, Su Y. Chronic Helicobacter pylori infection and ischemic stroke subtypes. Neurol Res. 2011; 33(5): 467-472.
53. Yu M, Zhang Y, Yang Z, Ding J, Xie C, Lu N. Association between Helicobacter pylori infection and stroke: a meta-analysis of prospective observational studies. J Stroke Cerebrovasc Dis. 2014; 23(9): 2233-2239.

54. Gabrielli M, Santoliquido A, Cremonini F, Cicconi V, Candelli M, Serricchio M, Tondi P, Pola R, Gasbarrini G, Pola P, Gasbarrini A. CagApositive cytotoxic $H$. pylori strains as a link between plaque instability and atherosclerotic stroke. Eur Heart J. 2004; 25(1): 64-68.

55. De BR, Gabrielli M, Ubaldi E, Benedetto E, Sanna G, Cottone C, Candelli M, Zocco MA, Saulnier N, Santoliquido A, Papaleo P, Gasbarrini G, Gasbarrini A. High Prevalence of Cag-A Positive $H$. pylori Strains in Ischemic Stroke: A Primary Care Multicenter Study. Helicobacter. 2008; 13(4): 274-277.

56. Pietroiusti A, Diomedi M, Silvestrini M, Cupini LM, Luzzi I, Gomez-Miguel MJ, Bergamaschi A, Magrini A, Carrabs T, Vellini M, Galante A. Cytotoxin-associated gene-A-positive Helicobacter pylori strains are associated with atherosclerotic stroke. Circ J. 2002; 106(5): 580584.

57. Cremonini F, Gabrielli M, Gasbarrini G, Pola P, Gasbarrini A. The relationship between chronic $H$. pylori infection, CagA seropositivity and stroke: meta-analysis. Atherosclerosis. 2004; 173(2): 253-259.

58. Zhang S, Guo Y, Ma Y, Teng Y. Relationship between the cytotoxin-associated gene-A status of $\mathrm{H}$ pylori strains and cerebral infarction in European Caucasians and Chinese Han: a meta-analysis. World J Gastroenterol. 2008; 14(8): 1286.

59. Pasceri V, Patti G, Cammarota G, Pristipino C, Richichi G, Di Sciascio G. Virulent strains of Helicobacter pylori and vascular diseases: a meta-analysis. Amer Heart J. 2006; 151(6): 1215-1222.

60. Xu Q, Kiechl S, Mayr M, Metzler B, Egger G, Oberhollenzer F, Willeit J, Wick G. Association of serum antibodies to heat-shock protein 65 with carotid atherosclerosis. Lancet. 1993; 341(8840): 255-259.

61. Sung JJ, Sanderson J. Hyperhomocysteinaemia, Helicobacter pylori, and coronary heart disease. Heart. 1996; 76(4): 305-307.

62. Markus HS, Mendall MA. Helicobacter pylori infection: a risk factor for ischaemic cerebrovascular disease and carotid atheroma. J Neurol Neurosur Ps. 1998; 64(1): 104-107. 
63. Honjo K, Van RR, Verhoeff NP. Alzheimer's disease and infection: do infectious agents contribute to progression of Alzheimer's disease? Alzheimers Dement. 2009; 5(4): 348360.

64. Kountouras J, Boziki M, Gavalas E, Zavos C, Grigoriadis N, Deretzi G, Tzilves D, Katsinelos P, Tsolaki M, Chatzopoulos D, Venizelos I. Eradication of Helicobacter pylori may be beneficial in the management of Alzheimer's disease. J Neurol. 2009; 256(5): 758-767.

65. Kountouras J, Tsolaki M, Gavalas E, Boziki M, Zavos C, Karatzoglou P, Chatzopoulos D, Venizelos I. Relationship between Helicobacter pylori infection and Alzheimer disease. Neurology. 2006; 66(6): 938-940.

66. Kountouras J, Boziki M, Gavalas E, Zavos C, Deretzi G, Grigoriadis N, Tsolaki M, Chatzopoulos D, Katsinelos P, Tzilves D, Zabouri A. Michailidou Increased cerebrospinal fluid Helicobacter pylori antibody in Alzheimer's disease. Int J Neurosci. 2009; 119(6): 765-777.

67. Bjarnason IT, Charlett A, Dobbs RJ, Dobbs SM, Ibrahim MA, Kerwin RW, Mahler RF, Oxlade NL, Peterson DW, Plant JM, Price AB, Weller C. Role of chronic infection and inflammation in the gastrointestinal tract in the etiology and pathogenesis of idiopathic parkinsonism. Helicobacter. 2005; 10(4): 276-287.

68. Pierantozzi M, Pietroiusti A, Brusa L, Galati S, Stefani A, Lunardi G, Fedele E, Sancesario G, Bernardi G, Bergamaschi A, Magrini A, Stanzione P, Galante A. Helicobacter pylori eradication and I-dopa absorption in patients with PD and motor fluctuations. Neurology. 2006; 66(12): 1824-1829.

69. Schulz J, Hawkes E, Shaw C. Cycad toxins, Helicobacter pylori and parkinsonism: cholesterol glucosides as the common denomenator. Med hypotheses. 2006; 66(6): 1222-1226.

70. Taye B, Enquselassie F, Tsegaye A, Medhin G, Davey G, Venn A. Is Helicobacter Pylori infection inversely associated with atopy? A systematic review and meta-analysis. Clin Experiment Allergy. 2015; 45(5): 882-890.

71. Sheptulin A. Helicobacter pylori infection: what else besides gastric problems? Klin Med. 2013; 92(5): 33-39.

72. Reibman J, Marmor M, Filner J, FernandezBeros ME, Rogers L, Perez-Perez GI, Blaser MJ. Asthma is inversely associated with Helicobacter pylori status in an urban population. PloS One. 2008; 3(12): e4060.
73. Arnold IC, Dehzad N, Reuter S, Martin H, Becher B, Taube C, Müller A. Helicobacter pylori infection prevents allergic asthma in mouse models through the induction of regulatory $\mathrm{T}$ cells. J Clin Invest. 2011; 121(8): 3088-3093.

74. Nasif WA, Mukhtar MH, Nour Eldein MM, Ashgar SS. Oxidative DNA damage and oxidized low density lipoprotein in Type II diabetes mellitus among patients with Helicobacter pylori infection. Diabetol Metab Syndr. 2016; 8(1): 34.

75. Upala S, Jaruvongvanich V, Riangwiwat $T$, Jaruvongvanich S, Sanguankeo A. Association between Helicobacter pylori infection and metabolic syndrome: a systematic review and meta-analysis. J Dig Dis. 2016; 17(7): 433-440.

76. Hsieh MC, Wang SS, Hsieh YT, Kuo FC, Soon MS, Wu DC. Helicobacter pylori infection associated with high $\mathrm{HbA} 1 \mathrm{c}$ and type 2 diabetes. Eur J Clin Invest. 2013; 43(9): 949-956.

77. Kazerooni T, Taallom M, Ghaderi A. Helicobacter pylori seropositivity in patients with hyperemesis gravidarum. Int J Gynecol Obstet. 2002; 79(3): 217-220.

78. Koçak I, Akcan Y, Ustün C, Demirel C, Cengiz L, Yanik FF. Helicobacter pylori seropositivity in patients with hyperemesis gravidarum. Int $\mathrm{J}$ Obstet Gynecol. 1999; 66(3): 251-254.

79. Frigo P, Lang C, Reisenberger K, Kölbl H, Hirschl AM. Hyperemesis gravidarum associated with Helicobacter pylori seropositivity. Obstet Gynecol. 1998; 91(4): 615-617.

80. Aytac S, Türkay C, Kanbay M. Helicobacter pylori stool antigen assay in hyperemesis gravidarum: a risk factor for hyperemesis gravidarum or not? Digest Dis Sci. 2007; 52(10): 2840-2843.

81. Larraz J, Marin N, Piñeiro L, Cilla G, PérezTrallero E. Lack of relationship between infection by Helicobacter pylori and vomiting that usually occurs during pregnancy, although possible relationship with severe forms of emesis. Rev Esp Enferm Dig. 2002; 94(7): 417-422.

82. Arslan E, Atılgan H, Yavaşoğlu I. The prevalence of Helicobacter pylori in obese subjects. Eur J Endocrinol. 2009; 20(7): 695-697.

83. Zhang Y, Du T, Chen X, Yu X, Tu L, Zhang C. Association between Helicobacter pylori infection and overweight or obesity in a Chinese population. J Infect Dev Ctries. 2015; 9(09): 945-953.

84. Ioannou G, Weiss N, Kearney D. Is Helicobacter pylori seropositivity related to body mass index 
in the United States? Aliment Pharm Therap. 2005; 21(6): 765-772.

85. Wu MS, Lee WJ, Wang HH, Huang SP, Lin JT. A case-control study of association of Helicobacter pylori infection with morbid obesity in Taiwan. Arch Intern Med. 2005; 165(13): 1552-1555.

86. Pacifico L, Anania C, Osborn JF, Ferrara E, Schiavo E, Bonamico M, Chiesa C. Long-term effects of Helicobacter pylori eradication on circulating ghrelin and leptin concentrations and body composition in prepubertal children. Eur $\mathrm{J}$
Endocrinol. 2008; 158(3): 323-332.

87. Azuma $T$, Suto $H$, Ito $Y$, Muramatsu A, Ohtani M, Dojo M, Yamazaki Y, Kuriyama M, Kato T. Eradication of Helicobacter pylori infection induces an increase in body mass index. Aliment Pharm Ther. 2002; 16(s2): 240-244.

88. Nweneka CV, Prentice AM. Helicobacter pylori infection and circulating ghrelin levels-a systematic review. BMC Gastroenterol. 2011; 11(1): 7 . 